\title{
Class and politics in the work of Henry Pelling
}

\author{
Alastair J. Reid
}

In the ranks of that distinguished generation of post-war British academics who established labour history on a professional footing, Henry Pelling is generally regarded as worthy but rather dull. For he did not share the more colourful far-left political affiliations of figures such as Eric Hobsbawm and Edward Thompson. Indeed, when these Marxists were at the height of their influence in the late 1960s and 1970s, Pelling's careful history of the British Communist Party was frequently dismissed as Cold War propaganda. At that time his contributions to the history of the Labour Party were commonly pigeon-holed as scholarly but narrow, for they were seen as mere political history with no obvious wider implications for the analysis of society as a whole. As Jay Winter (1983: x) put it, albeit respectfully, in the Introduction to a collection of essays in Pelling's honour:

In place of what may be called the 'sixty years' march syndrome' of labour history, Pelling quietly and authoritatively provided ... a rigorous and accurate account of the evolution of the institutions of the modern labour movement ... In a sense, his political histories have helped to fulfil the classic aim of historical scholarship: the replacement of mythology or vague memory by painstakingly-researched and documented historical analysis.

At the same time, many modern British political historians, increasingly interested in Labour's replacement of the Liberals as the main party of progress, were associating Henry Pelling's name with an interpretation of the rise of Labour based on broader social trends. Thus, in one popular survey, Paul Adelman (1972: 87) outlined the work of a school of historians who emphasised the extent to which the Liberals' political base had decayed before the outbreak of the First World War:

Pelling, for example, has emphasized repeatedly the enormous importance of increasing trade union affiliations for future Labour development ... Moreover, he stresses the importance of those more general social and economic factors - growing difficulties in basic industries like coal, for example, coupled with increasing geographical unity on the one hand but deeper class divisions on the other - which were bound eventually to play into the hands of the Labour Party. 
Indeed, Winter claimed that Pelling had been able to bridge the divide between the approach associated with an older generation of historians, who emphasised activism and struggle, and that of a younger generation, more concerned with popular Conservatism and apathy. In that sense he considered that Pelling had made an influential contribution to 'a better understanding of the multiple political and social meanings of the experience of class in modern Britain' (Winter 1983: xi).

\section{Early career}

Clearly there are some threads to be disentangled here, and it may be helpful to begin with some biographical information. Like most of the other members of the founding generation of labour historians, Pelling's early life was dominated by a combination of studying history at Cambridge University and serving in the armed forces during the Second World War (Winter 1983: viii). Indeed, he came from a conventional upper-middle-class family and started out with classics, so it was the interruption of his studies by the experience of military service which turned him towards more progressive politics and more recent history. Perhaps because this shift in his interests coincided with the Labour Party's landslide election victory of 1945 and the urgent tasks of post-war reconstruction which it then faced in government, Pelling was never attracted to the Communist Party. On the contrary, his role as secretary of his university Labour Party and Fabian Society allowed him to meet such memorable celebrities as the Cabinet Minister Hugh Dalton. Meanwhile, one of the more significant influences among his teachers was the economic historian Michael Postan, an outspokenly anti-Marxist East European emigré, close to figures on Labour's right wing such as Hugh Gaitskell. Moreover, Pelling's subsequent doctoral research on the early history of the ILP brought him into personal contact with many of the by-then-elderly pioneers of British Labour politics, and he struck up particularly warm relationships with such ethical socialists as Kathleen Bruce Glasier.

As already indicated, when this research began to appear in published form it had something of a paradoxical character. For, on the one hand, Pelling paid a great deal of attention to the detail of political events. In his own words at the beginning of his first major work, The Origins of the Labour Party: 'This book is an attempt to describe how the Labour Party came into existence. It is primarily a study in the development of new political structure' (Pelling 1954a: v). He looked in particular at the leadership, the ideas and the interaction between such small groups as the Social Democratic Federation (SDF), the Socialist League, the Fabian Society and the ILP. And his sources were largely institutional ones: the newspapers, pamphlets and minute books of these organisations, supplemented where possible by correspondence between their leaders, which he had frequently collected himself from those directly involved. On the other hand, however, Pelling also sometimes accounted for long-term political trajectories in much broader social terms. Thus he concluded his 'Introduction' by discounting the influence of political thought on the emergence of the Labour Party, emphasising instead 'the continually 
increasing importance of the "labour interest" in a country which, with a maturing capitalist economy and a well-established class system, was now verging on political democracy' (Pelling 1954a: 12).

Given the political and intellectual context in which his own basic approach had been formed, it would have been surprising had there been no comments of this sort in Pelling's work. For Labour's triumph in the general election of 1945, and the creation of the National Health Service and the nationalisation of leading industries that followed, were widely seen as the fulfilment of earlier socialist predictions about the evolution of modern industrial societies. There may have been some brief setbacks on the way, but history seemed to be on their side and to have turned in their direction gratifyingly quickly, indeed within the space of one lifetime. It was, after all, only forty-five years since the foundation of the Labour Party, and only sixty years since the emergence of the earliest modern socialist groups.

Perhaps that was all there was to it: Pelling had intended to write only narrow political history, but had been swept along by the surrounding atmosphere into making unguarded comments reflecting the times he lived in rather than his own considered judgements. His contribution to the history of the Labour Party would therefore best be appreciated by discarding the dated chaff of his more general remarks in order to preserve the fertile seed of his detailed institutional analysis. And his reputation would remain worthy but still dull.

The remainder of this chapter suggests, however, that to do so would be a misunderstanding of the way he opened up the serious historical study of the Labour Party, and that it would risk leaving out the core of his own interest and motivation. The first two sections look more closely at Pelling's early work on the origins of the Labour Party and show how it was based on a coherent, if theoretically understated, conception of class and politics in modern Britain. The third section examines some of Pelling's unpublished papers to explore the influences on his thinking of a distinctive and, for an allegedly dull historian, perhaps surprisingly continental strand of socialist thought. More broadly, this chapter hopefully demonstrates that a position sympathetic to the moderate mainstream of the Labour Party, rather than to the Communist Party or the New Left, does not need to be intellectually uninteresting.

\section{The Origins of the Labour Party}

The apparent paradox in Pelling's work was already evident at the start of his first major book. For The Origins of the Labour Party (1954a) begins by accounting for organised labour's adherence to the Liberal Party in the 1860s and 1870s in specifically political terms, as a result of the restricted franchise and limited financial resources, alongside the appeal of William Gladstone's progressive policies. But it then goes on to introduce the changes of subsequent decades with the broader social claim that 'large-scale industry developed a class solidarity among the workers which in the end facilitated effective political action in the interest of labour as a whole' (1954a: 4). More careful consideration, however, reveals aspects of this claim that otherwise may not be immediately obvious. 
Firstly, the conception of 'class solidarity among the workers' was not framed in orthodox Marxist terms as a reduction of distinctive positions to a lowest common denominator of economic deprivation, leading eventually to a bitter political revolt. Rather it was seen in quietly revisionist terms as an increase in material wellbeing and organisational strength, leading to a growing capacity for constructive political reform. Thus Pelling followed the passage cited above with a description of the establishment of the Trades Union Congress (TUC) in the late 1860s, its success in improving the legal status of trade unions, the rising expectations of the craft bodies and the first signs of organisation among less-skilled workers in the early 1870 s.

This period of progress was soon followed by a long economic depression which, contrary to orthodox Marxist predictions, 'so far from encouraging Socialism and the break-up of the Liberal Party, actually discouraged working-class militancy and destroyed the "advanced" elements then in existence' (1954a: 6). However, the more positive dynamic was reasserting itself by the late 1880s, for 'throughout the last half of the century the effective political strength of labour was almost constantly increasing: the growth of industry, the improvement of real wages and conditions, and the extension of educational facilities all combined to maintain this long-term trend' (1954a: 7). Even in discussing the widespread feeling of insecurity in the trade union world following the defeat of the engineers by an aggressive employers' lockout in 1897, Pelling was still at pains to highlight the distinctive conditions affecting each organisation. Thus long-term unemployment in metalworking, new technology in shoemaking and printing, and poor working conditions on the railways were neither reduced to one underlying trend nor seen as leading to any kind of revolt against the system: 'the attitude of the bulk of the unions now favouring independent labour representation was dictated more by fear for the security of their existing position than by the hope of any millennium' (1954a: 211). Moreover, it was just as important that they had been able to build up the financial reserves to allow them to do something about it.

Secondly, the nature of 'effective action in the interest of labour as a whole' would be fundamentally shaped by the political terrain to be traversed. In the British case this meant above all that any attempt to turn it in a revolutionary direction would lead to a dead end. Thus, in reviewing the trajectories of different socialist groups in the Conclusion to The Origins of the Labour Party, Pelling remarked that 'the British working class as a whole had no use for the conception of violent revolution. Any leader who failed to recognise this could not expect to win widespread support' (1954a: 231). Indeed the leader of the SDF, H. M. Hyndman, had already been dismissed in a way which was humourously appropriate both in itself and in its application to later generations of would-be revolutionaries:

Hyndman saw himself as the Chairman of the Committee of Public Safety, installed in office by an untutored but enthusiastic mob aroused to violence by the bitterness of capitalistic crisis. It was an entertaining if somewhat unreal expectation that he, the City man, complete with the frock-coat and top-hat which were his customary dress, should be borne to power as the workers' choice in order to inaugurate the dictator- 
ship of the proletariat. History has seen many ironies, but this was one which it was not to tolerate. (1954a: 49)

In addition to the revolutionaries' underestimation of the intelligence of ordinary people and misunderstanding of the impact of economic circumstances, this was also due, in Pelling's view, to the extension of political democracy in late nineteenth-century Britain. For working men were increasingly able to express their views peacefully through the doubling of the national electorate by the 1884 Reform Act, accompanied by less dramatic but equally important legislation of 1882-83 removing the property qualifications for candidates in borough elections and preventing most methods of bribing voters. Moreover, the wider background to such appeal as socialism did have in the British context was strongly coloured by radical land reformers like Henry George and backward-looking cultural critics like Thomas Carlyle and John Ruskin. Thus among the early socialist groups it was the Fabian Society's decision to adopt constitutional reformism and evolutionary gradualism that provided an appropriate application of Marxist social theory to British political conditions as well as synthesising it with indigenous intellectual traditions.

Thirdly a grasp of the correct overall strategy would, however, rarely be enough, for political success also depended on being able to choose the right tactics. Thus, while Fabianism provided an accurate analysis of trends in British society and politics, it made little contribution to the foundation of the Labour Party because its leading figures, based as they were in London, became too bound up in futile attempts to permeate the existing Liberal and Conservative Parties. By contrast, other reformist socialists committed themselves to building up independent labour representation by following the example of the Irish Nationalists, who had obtained concessions by securing the election of a group of MPs large enough to hold the balance of power in the House of Commons. The most prominent among this type was Keir Hardie, from the west of Scotland, who combined this parliamentary ambition with the struggle to build an alliance between his ILP and the TUC in order to tap the latter's financial resources, eventually leading to the foundation of the Labour Representation Committee (LRC) in 1900. Although Hardie had begun as an enthusiastic Gladstonian Liberal, his personal experience of the brutal conditions of the coalmining industry led him to advocate a break with both existing parties from surprisingly early in his political career:

Labour questions, thought Hardie, should take precedence over all other questions, and working men irrespective of party should combine to effect this. Nor was this, he considered, an impossible task: for even without further constitutional reform, working men could exert a decisive influence at Westminster. But it could only be done if those who were sent to Parliament to represent labour were bound to a definite labour programme. (1954a: 75)

Fourthly, the effectiveness of the tactics chosen would be vitally dependent on the responses of significant political opponents and rivals. Thus the sharp growth in trade union affiliations to the LRC after 1901 was a result of the latest manifestation of hostile judge-made law in the Taff Vale ruling. This stipulated that, 
although individual leaders were now safe from being sued through the courts for criminal conspiracy for their actions during industrial disputes, the unions as organisations could be sued for civil conspiracy and the amounts involved in payments of damages to employers could be very substantial. Even more vitally, the growing momentum of the LRC within the overall 'progressive alliance' between organised labour and middle-class liberalism was the result of the stubborn resistance of the local Liberal Parties to the adoption of trade union candidates, despite consistent pressure in that direction from their national organisers:

All along, there is little doubt that most of the non-Socialist trade-union leaders would have been happy to stay in the Liberal Party - which most of them had belonged to in the past - if the Liberals had made arrangements for a larger representation of the working class among their Parliamentary candidates ... Even Keir Hardie's revolt at Mid-Lanark in 1888 had been directed, not against the policy of Gladstone, but against the system by which the local association chose its candidate. (1954a: 235-6)

Yet the Liberal leadership itself was not exempt from criticism for its handling of the new political currents, for it proved to be surprisingly slow in pressing seriously for the state payment of MPs' salaries and of returning officers' fees, both reforms which might have helped to retain the loyalties at least of the smaller trade unions.

Fifthly, and finally, a complete historical account of effective political mobilisation would require not only an evaluation of the intellectual analysis available but also an appreciation of the level of emotional commitment involved. Here, as Pelling made clear in reviewing a collection of essays on Sidney and Beatrice Webb, was another major weakness of the Fabians:

The paradox of the Webbs was that, fundamentally, they did not understand politics ... They knew how institutions worked, and within certain limits they could work them; but they could not measure the forces that transmuted and transcended these institutions - the elemental forces of political power. 'Marriage', said Beatrice, 'is the wastepaper basket of the emotions'. She did not realize that the same could be said of politics or indeed of almost every field of human endeavour. (Pelling 1950: 507)

By contrast, the success of the early ILP was bound up with its quasi-religious outlook and the powerful motivating force of its members' passionate faith in the ultimate victory of their cause. Indeed, a strictly accurate estimate of resources and prospects was not always advisable:

It does not matter if the faith feeds on illusions, for it is capable of conquering reality ... It was this crusading zeal which drew attention to the Socialists in the eighties, and enabled them ... to have an influence in politics far beyond what their numbers justified. (Pelling 1954a: 229-30)

Drawing on the deep traditions of popular religious nonconformity was probably inevitable, given the family backgrounds of most of those involved, and this bedrock of emotional attitudes was fundamental to the ILP activists' sense of purpose and enthusiasm. It was also fundamental in shaping their public performances, especially in the case of Hardie and Philip Snowden, both of whom delivered speeches consciously based on the sermonising techniques of evangelical revivalism. 


\section{Labour and politics}

For Pelling, then, class was intimately bound up with politics. In so far as there were important 'pre-political' elements of 'class solidarity among the workers', providing an underlying foundation, they were not confined to material forces. For they included not only such economic trends as larger workplaces and higher wages, but such social trends as increasing education and literacy, and such cultural and religious traditions as literary Romanticism and popular nonconformity. But class, for Pelling, was not something which impinged on politics from the outside; rather it was to a very large extent the result of political processes. The choice of strategy and tactics, the response of rivals and the mobilising of emotion among potential supporters were all vital elements in facilitating 'effective political action in the interest of labour as a whole'. Indeed, he was later to comment of the ILP leaders that 'by their constant emphasis on the importance of "labour representation" they had done much to foster the growth of class solidarity' (Bealey and Pelling 1958: 283). Thus The Origins of the Labour Party concluded with a passage which begins by celebrating the formation of a permanent party, moves on to highlight its dependence on human agency and ends on what might be read, in the increasingly faction-ridden 1950s, as a note of warning:

$[\mathrm{T}]$ he unity of the party, once established, remained substantially intact, and in the first half-century of its life, every General Election but two that it fought resulted in an increase of the aggregate Labour poll. The association of Socialist faith and tradeunion interest, of hope for an ideal future and fear for an endangered present, seemed on the point of disruption at times: yet it survived, for a variety of reasons which lie outside the compass of this book, but also because in the years before the party's birth there had been men and women who believed that the unity of the working-class movement, both in industry and politics, was an object to be striven for, just as now most of their successors regard it as an achievement to be maintained. (1954a: 241)

Pelling, then, was clearly not an orthodox Marxist; nor, despite his close attention to institutions, was he a straightforward Fabian. The Origins of the Labour Party, as its very title suggests, did contain significant teleological elements, for it identified those chains of events which led to the end-point of the foundation conference in 1900. However, his immersion in the study of the late nineteenth century was deep enough for Pelling to have detached himself from the inevitable evolution assumed by most of his left-wing contemporaries. Instead he was able to pay attention to the ways in which the two older parties had also been able to reconstruct genuine appeals, even under a more democratic franchise. For the Liberals had been able to draw on the traditions of nonconformity and temperance, and under Gladstone become associated with highly emotional struggles for the extension of the franchise and a democratic foreign policy. Meanwhile, the Conservatives, partly defined in opposition as the party of the established Church and the brewing trade, had actively associated themselves with such equally emotive issues as paternalistic social reform and hostility towards immigrants. A Labour Party had undoubtedly emerged, but there had been nothing inevitable about it 
and, though active in a rapidly changing social context, the party was to remain deeply influenced by the political background out of which it had stepped:

Its principal leaders were all ex-Liberals, many of them Liberals still in all but name; and the object of its policy in its first thirty years of life seemed to be not so much to win the confidence of the whole working class as to supplant the Liberal party. In this aim it succeeded, and by the nineteen-twenties it had become the party of the Celts and the nonconformists, of the teetotallers and the pacifists. The process of adaptation to make it a national party and to redress its bias of old Liberalism seems to be still in progress, not having gone all the way when the party attained power for the first time in 1945. (Pelling 1953: 238)

It should now be clear that for Pelling political agency and the legacies of previous political actions were the decisive factors in understanding the origins and nature of the Labour Party. Social trends did provide important material for politicians to work with, and on the whole those in Britain favoured increasingly effective democratic reformism. However, there was no concession to any notion of a unified working class as the basis for explanations of political behaviour. On this issue there is a clear line to be drawn between Henry Pelling's approach and those not only of contemporary orthodox Marxists such as Eric Hobsbawm, but of younger post-Marxists such as Gareth Stedman Jones and Ross McKibbin. For all of these other historians assumed the economic formation of a homogeneous working class in late nineteenth-century Britain and consequently saw the main task as being to explain its lack of interest in socialism, let alone revolution (Hobsbawm 1984; McKibbin 1990; Stedman Jones 1983; and for further discussion of these issues see Reid 1995). In some contrast it is striking that in his second major work, Labour and Politics, 1900-1906, written jointly with Frank Bealey, Pelling went out of his way in his introductory chapter to emphasise that, even after the formation of the Labour Party, popular attitudes remained highly fragmented along regional lines. This was a development of his long-standing interest in the very different characteristics of labour politics in the south and the north, partly already explained as a result of the more open and more radical nature of London Liberalism, but now increasingly also seen as a result of deeper cultural traditions. To some extent these might be understood in terms of the relationship between each region and the central State. For example, on the issue of the Boer War, which was just coming to an end at the time of Labour's foundational conference, the adoption of political positions 'was largely determined by traditional sectional loyalties which in some cases had been maturing since the Middle Ages. The Welsh, the Irish, and to some extent the Scots, with the aid of the English religious dissenters, stood against the tide of Imperialism' (Bealey and Pelling 1958: 2).

As that statement itself indicates, however, Pelling was increasingly concerned with the impact of religious affiliations. Characteristically, this was to be understood less in terms of the intellectual or moral teachings of the churches and more in terms of such pragmatic influences as family environment and denominational schooling. Thus, having charted the local levels of attendance at Church of England schools and shown their striking correlation with levels of support for the 
Conservative Party in the same areas, Pelling concluded that 'this classification provides a much better index of political feeling for provincial England than any that is simply based on class differentiation or degree of industrialisation' (Bealey and Pelling 1958: 5). Most of the urban industrial regions showed a characteristic combination of nonconformity and popular Liberalism, and the major exceptions could now be understood in religious terms. In particular, the regional strength of Anglicanism helped to account for the Conservative bias of Lancashire, while the weakness of all denominations in the much more mobile context of the metropolis helped to account for the more secular and materialist tone of politics in London. Indeed the influence of religious affiliation was seen as part of the explanation for regional variations in the appeal of the newer socialist bodies themselves, with the rationalist and anti-clerical Fabians and SDF making more headway in Lancashire and London, while the idealist and evangelical ILP had a greater appeal in nonconformist areas, especially in the north.

Nor was this tendency towards the regional fragmentation of politics seen as being counteracted by the growth of trade unionism. For, despite its intimate connection with economic inequality, that too remained marked by weakness and sectionalism. The degree of unionisation varied markedly across occupations, with agricultural labourers still being the largest single group but barely organised, while the centres of manufacturing industry were still, as often as not, characterised by small firms, out-work and non-unionism:

Industrialisation, always a catalyst of change, transformed the social structure sufficiently to bring new political forces into play: but since the new industries grew up in a piecemeal, localised fashion, the national pattern was hardly less variegated than before. (Bealey and Pelling 1958: 284)

Thus even those occupations that did have a significant union presence still tended to be found in particular industrial districts and were merged into regional political traditions. Cotton-workers were mainly concentrated in Lancashire, strongly influenced by local Conservatism and therefore less motivated towards direct labour representation. Coalminers were dispersed in a number of county unions, usually in nonconformist districts, so, while able and willing to elect significant numbers of their own officials as MPs, still found a congenial home within the Liberal Party. Meanwhile, those groups like the metalworking craftsmen who did have more of a national presence were usually spread too thinly to be able to influence political outcomes in particular constituencies.

Direct labour representation had taken a new form with the LRC in 1900 and worked up enough momentum in the general election of 1906 to adopt the grander title of the Labour Party. But Pelling was underlining the factors which meant that for most of the century to come Labour would experience enormous difficulties in constructing a governing majority:

Both in Parliament and out, the stresses and strains of the party structure revealed themselves, as they had done earlier, in controversy, in recrimination, even in secession. In these events we can see the very essence of British politics - the social, industrial, and religious differences, the peculiarities of local situations, the interplay of 
environment, of personality, and even of sheer accident. Nor is this surprising. The story of a great political party contains within itself the history of a nation. (Bealey and Pelling 1958: 288)

Note again that ending: the history of a nation, not the history of a class. For the lasting value of Henry Pelling's work is not just to be found in his commitment to accurate archival research, pioneering though that was in its day, but above all in his determination to locate the history of labour within the history of the country as a whole. This is a challenge which still needs to be taken up more widely if labour history is to find its rightful place once again at the centre of our understanding of the recent past.

\section{Socialism and democracy}

Thus far, this account has been based on a close reading of Pelling's published work, and elements of it may therefore be quite familiar. At least it should have demonstrated that he was an unusually intelligent historical observer, but it may still appear that he was only stumbling on insights in the course of narrow, empirically defined research projects. However, a number of unpublished papers delivered to a variety of university audiences in the late 1940s present a very different picture. For here we find Pelling involved in a series of rigorous encounters with socialist thought and prepared to make broad generalisations. Initially surprising in relation to his later public reputation, this is less so when we consider their original context. For both the author and many of those in his audiences had just been de-mobbed from a costly war against German Nazism only to be confronted with the intensification of a Cold War against Russian communism. Much has been made of this highly charged ideological context in relation to the distinguished group of Marxists who emerged from the discussions of the Communist Party Historians' Group. From what follows it should be clear that this appreciation needs to be broadened to include the more moderate mainstream of the university Left of that period (for some aspects of the intellectual environment in Cambridge University at the time see Taylor 1997; for the unusual German ethical-socialist influences on Allan Flanders, a parallel figure in the field of industrial relations, see Black 1999 and Kelly 1999).

Already in what seems to be the earliest of these papers, probably given to an informal audience of research students while he was working on his doctoral dissertation on the early history of the ILP completed in 1950, Pelling made it quite clear that his motivation was to produce work that was 'relevant to contemporary problems and future action' (Pelling nd a: 1). Moreover, he explained that his initial institutional focus was meant only as a point of entry to a much larger field:

Its formal structure is a foundation for one's studies, which will then be able to extend and broaden until one can appreciate the wider historical perspectives, and if desired, comprehend the philosophical and political thought of the period and its general social attitudes. (Pelling nd a: 5) 
Such wider perspectives were indeed explored in the most revealing of those unpublished talks, 'Socialism and democracy', given on the centenary of The Communist Manifesto in 1948. For on that occasion Pelling was prepared to make a clear distinction between the principles of Marxist social theory and the variety of political strategies which could legitimately be derived from them. He quoted at length from Engels on the broad theory of historical materialism and underlined its prophetic anticipation of the emergence of independent working-class politics. However, he also argued that Marx and Engels themselves had deliberately left some room for manoeuvre in particular national circumstances and it had only been Lenin who had insisted on the necessity of the violent overthrow of the bourgeois state. In contrast, Western European reformists, especially in France and Germany, had argued that in certain countries the tradition of democratic government had developed sufficiently for the class struggle to be modified into constitutional channels' (Pelling 1948: 6). Thus it would seem as if Pelling's understated historical observations on the improvement of economic conditions and the extension of the franchise in late nineteenth-century Britain were not just chance insights, but rather were connected to a familiarity with the emergence of revisionist trends within Western European Marxism. In other circumstances the public presentation of his work might have taken a different form, but the intensity of the Cold War at the time hemmed him in on both sides. For the label 'Marxist' was largely restricted to the Soviet-aligned communist parties, while any innovative references to historical materialism were likely to attract only Stalinist rebukes:

$[\mathrm{O}]$ ne might say that what distinguishes Marx from earlier thinkers is simply his application of scientific method to history and his discovery of the central importance of economic motivation. Any political thinker who follows in the path of Marx and who develops his doctrine still further and in so doing modifies his conclusions or introduces new complications into an apparently simple picture at once lays himself open to accusations from what I might call the theological Marxists, the patristic commentators, of deviating from the true 'line' of Marxist thought. In so far as I deal with developments in the twentieth century I shall therefore attempt to avoid confusing meanings by [not] introducing the word Marxist in any sense at all. (Pelling 1948: 4)

Pelling, then, was familiar with Marxist theory and prepared to locate himself in relation to it, but even without the Cold War he would probably have found that tradition too constraining. For in the context of the debates on strategy within the Second International, it was the eclectic ethical socialism of Jean Jaures that he found particularly attractive. The reference to Jaures is to his interventions at the 1903 Bordeaux Congress of the French Socialist Party, during which he was attempting to find a middle way between reformists and revolutionaries, increasingly divided on the issue of joining a coalition government. Pelling probably came across this speech in R. C. K. Ensor's Modern Socialism (1904: 163-86), which was part of his own private collection of books, and which contained a wide selection of British, French and German socialist texts. The middle way of Jaures gave Pelling a more general framework for understanding that parliamentary politicians were 
likely to be tempted to join coalition governments and make too many compromises, and for concluding that this could be avoided only if reformist parties remained firmly based on the extra-parliamentary movements of the working class, 'that is, upon those who have suffered most from the inequalities of the present social system' (Pelling 1948: 16; for the reception of Jaures in Britain in the 1900s, see Tanner 1991). This seems to have been particularly appealing as an antidote to the traumatic memory of Labour's former leader Ramsay MacDonald's formation of the National Government in 1931, its subsequent imposition of a cut in the level of unemployment benefit in the face of strong opposition from the TUC, and a near-fatal split in the Labour Party:

The Socialist party [Jaures argues] must defend democratic liberties; it must be mindful of the national culture; yet it must bear in mind the possibility of violent capitalist reaction using the State machinery against the proletarian class, and therefore it must safeguard its hold upon the sympathies of the workers and retain its defensive organisation of their interests. (Pelling 1948: 8)

This would suggest, therefore, that Pelling's appreciation of the ILP's tactics of independent labour representation was not just the result of a pragmatic evaluation of their important contribution to the foundation of the Labour Party, but reflected a deeper sense of the ethical basis of political action and the moral responsibilities of democratic politicians.

Familiarity with these general principles in continental socialist thought also led him to a number of broad conclusions about the peculiar nature of British historical development, with a special focus on the ways in which it had further intensified existing Western European trends towards parliamentary reformism. Relative geographical isolation had protected the country from much of the political upheaval accompanying periodic waves of military aggression in the rest of Europe, and it had consequently been able to develop as a more continuous unified state with a stronger parliamentary tradition. The former had contributed to a widespread sense of the complexity of national affairs and the inappropriateness of dealing with them through such channels of direct democracy as popular assemblies, the election of delegates and the use of referenda. The latter had evolved as a combination of an electoral system which gave the strongest party in the country a majority of seats in the House of Commons and a custom of forming governments which then gave that majority a complete monopoly of cabinet offices. Socialist activists in Britain took this so much for granted that they rarely reflected on its peculiar propriety to their own political project:

a system which, in spite of being undemocratic, or rather perhaps because of it, is admirably suited to express in constitutional form not only the idea of the class struggle, but also the concept, apparently so unconstitutional, of the dictatorship of the proletariat. The agency of this dictatorship would be the cabinet, which is both the central authority of initiative in legislation and the final arbiter of executive policy. (Pelling 1948: 12)

It was characteristic of Pelling's approach both that the peculiarities of British development should thus have been seen in terms of political rather than 
economic or social structures, and that these broad outlines should have been followed immediately by an account of specific political actions. For against this background there had still been a lively debate on the British Left involving Marxist and syndicalist rejection of the parliamentary road, and ultra-radical calls for a major overhaul of the constitution. Although in the end Pelling judged that MacDonald had gone too far in the direction of parliamentary reformism, it had been his consistent political intelligence and effective leadership that had kept the early Labour Party on a peaceful and gradualist path more appropriate to British conditions:

What a contrast there is between this and Leninism! The Bolshevik theory has been defined as Socialism while you wait, or rather Socialism while you won't wait; and for some countries, unfortunately, it may be the only approach to Socialism that is possible. But this country, which has already benefited by peaceful transfers of power from older to newer aristocracies in earlier centuries, will permit the internal transformation of institutions while retaining the outward forms of those institutions comparatively unchanged. (Pelling 1948: 14. For the importance of MacDonald's contribution see also Pelling nd a: 16, and Pelling nd b: 1-2, 9-10)

These reflections on British history by a Labour moderate in the late 1940s strikingly anticipated the more open-minded and imaginative debate which became possible among Marxists after the splits in the communist world over the Soviet acknowledgment of Stalinist excesses in 1956. Indeed, Pelling's emphasis on the impact on Labour reformism of the survival of aristocratic power and traditional institutions in Britain was remarkably close to the position later taken by such leading figures among the younger generation of the New Left as Perry Anderson and Tom Nairn, though of course in their case the analysis was inflected with tones of bitter regret (Chun 1993: 69-76; Reid 1978).

Given the overall framework of Pelling's 'Socialism and democracy' talk as a reflection on one of the foundation texts of Marxism, it is not surprising that he referred frequently to 'the working class', and in his more specific comments on the British Labour Party clearly underlined the centrality to its constitution of 'working class organisations', most notably in the case of the trade unions which controlled a majority of votes at its annual conference. In his broader conclusions about the peculiarities of British development, however, he also emphasised that it was the country's relatively peaceful history and its high level of individual liberty which had allowed the open formation of a large range of voluntary associations, including dissenting churches and co-operative societies, and also the trade unions themselves. As a result, these

organisations, while often of working class origin, tend to cut across the direct distinctions of class conflict as defined by Marx; moreover, by exerting their strength in political action they have obtained important concessions from the State, concessions which associate them, if not with capitalism itself, at any rate with the so-called capitalist State. This accounts for a strong tendency in Britain to distrust Marx's theory of economic classes as a misleading abstraction from the complex structure of society. (Pelling 1948: 9; see also Pelling nd b: 1) 
Here, then, anticipating the trail of his later historical work, we can see how Pelling's encounter with socialist thought involved, first, a careful revision of many of its implications and applications and, then, a turning back again to undermine some of its key presuppositions. For, having emphasised amelioration, constitutionalism, political traditions and political agency, he went on to question the whole notion of class itself, at least in its application to the British context (for his very early interest in regional differences see Pelling nd a: 8-12).

\section{Still worthy, but dull?}

Henry Pelling's work on the early Labour Party was undoubtedly informed by the empirical method, with all that implies for the careful collection and open-minded consideration of the relevant evidence. However, the insights he produced were not the result of a blinkered stumbling about in the archives, but rather of a conscious interaction with key issues in Western European socialist thought. As already mentioned, the Cold War environment was one reason he did not make this more explicit, but another was his aversion to becoming trapped in an excessively rigid intellectual framework (though some broader thinking was indicated, in a muted way, in Pelling 1954b: 1-16). It seems likely that in this respect he consciously modelled himself on what he saw as a further distinctive strength of British Labour strategy:

The theory is there, but it is worked out empirically and is seldom coherently expressed. Like the British constitution, it has never been precisely formulated and committed to writing. The party has had its prophets and its visionaries; it has had its active apostles of its gospel, tireless and innumerable; but it has no summary creed and no constraining intellectual discipline. Perhaps this is an advantage, for future developments may require subtle modifications which would be difficult to make if everything had been set down once and for all on paper. (Pelling 1948: 18)

Perhaps, then, it has been a mistake to attempt to explain and clarify the ideas underpinning Pelling's work. But that may still be redeemed if we are able to keep them at the back of our minds as a kind of sounding board, rather than relying on them as a set of rules to be followed, which would only get in the way of a clear reconstruction of the peculiarities of historical processes as they are recorded in the complexities of historical evidence.

\section{References}

Unless indicated, the place of publication is London.

Adelman, P. (1972) The Rise of the Labour Party, 1880-1945

Bealey, F. and Pelling, H. (1958) Labour and Politics, 1900-1906. A History of the Labour Representation Committee

Black, L. (1999) 'Social democracy as a way of life: fellowship and the Socialist Union, 1951-9', Twentieth Century British History, 10:4

Chun, L. (1993) The British New Left, Edinburgh 
Ensor, R. C. K. (ed.) (1904) Modern Socialism. As Set Forth by Socialists in Their Speeches, Writings and Programmes

Hobsbawm, E. J. (1984) Worlds of Labour. Further Studies in the History of Labour

Kelly, J. (1999) 'Social democracy and anti-communism: Allan Flanders and British industrial relations in the early post-war period', in Campbell, A. McIlroy, J. and Fishman, N. (eds) British Trade Unions and Industrial Politics, vol. 1: The Post-War Compromise, 1945-64, Aldershot

McKibbin, R. (1990) The Ideologies of Class. Social Relations in Britain, 1880-1950, Oxford

Pelling, H. (nd a) 'The history of the Independent Labour Party', unpublished paper, currently in the author's possession

Pelling, H. (nd b) 'Socialism in British politics - up to 1914', unpublished paper, currently in the author's possession

Pelling, H. (1948) 'Socialism and democracy', unpublished paper, currently in the author's possession

Pelling, H. (1950) 'Review of M. Cole (ed.) The Webbs and Their Work', Cambridge Journal, 3:8

Pelling, H. (1953) 'H. H. Champion: pioneer of labour representation', Cambridge Journal, 6:4

Pelling, H. (1954a) The Origins of the Labour Party, 1880-1900

Pelling, H. (ed.) (1954b) The Challenge of Socialism

Reid, A. (1978) 'Politics and economics in the formation of the British working class. A response to H. F. Moorhouse', Social History, 3:3

Reid, A. J. (1995) Social Classes and Social Relations in Britain, 1850-1914, Cambridge

Stedman Jones, G. (1983) Languages of Class. Studies in English Working Class History, 1832-1982, Cambridge

Tanner, D. (1991) 'Ideological debate in Edwardian Labour politics: radicalism, revisionism and socialism', in Biagini, E. F. and Reid, A. J. (eds) Currents of Radicalism. Popular Radicalism, Organised Labour and Party Politics in Britain, 1850-1914, Cambridge

Taylor, M. (1997) 'The beginnings of modern British social history?' History Workshop Journal, 43

Winter, J. (1983) 'Introduction: labour history and labour historians', in J. Winter (ed.) The Working Class in Modern British History. Essays in Honour of Henry Pelling, Cambridge 